\title{
ALTRUISM AMONG ORGANIC RICE FARMERS IN YOGYAKARTA
}

\author{
Azizatun Nurhayati*, Irham \\ Departement of Agricultural Socioeconomics, Universitas Gadjah Mada, Indonesia \\ *Corresponding author: azizatun.nurhayati@ugm.ac.id
}

\begin{abstract}
The economic motive, such as a higher price, can be one form of motives for farmers to do farming with an organic system. On the other hand, environmentally-friendly farming in organic is a part of non-economic motives or is known with altruism in this research. The purpose of this study was to know more about the motives of farmers in undertaking organic farming, economic or non-economic motives. Respondents in this research were 29 organic farmers who had conducted organic cultivation for more than three years consistently. Measurement of economic motives and altruism is done by using a Likert scale questionnaire and were analyzed descriptively. The results showed that economic motives still dominated of farmers motive in organic rice farming $(65 \%)$. The level of altruism is measured for the rest of $35 \%$ and showed at the level of human altruism.
\end{abstract}

Keywords: Altruism, organic farming, motives

http://dx.doi.org/10.21776/ub.agrise.2020.020.2.1

Received 25 February 2020

Accepted 21 April 2020

Available online 30 April 2020

\section{INTRODUCTION}

The issue of organic farming today is an exciting thing to discuss. Increased public awareness of healthy lifestyles and efforts to make people more concerned about the environment are two things that are developing in the community. Environmental care communities in Indonesia have developed since the establishment of WALHI (Wahana Lingkungan Hidup Indonesia) in 1980, and the emergence of the Bina Sarana Bakti (BSB) organization, which is 1990 all of its lands uses organic farming systems. Meanwhile, the development of Sahani in Yogykarya in 1999 was the beginning of the growing organic trend in Yogyakarta (Ardiansyah, 2015).

According to IFOAM, the principles of organic farming include aspects of care, ecology, fairness, and health. The law of care means that organic agriculture aims to protect the environment and future generations as well. Ecological principles make this farming system work with nature and make natural life sustainable. The principle of justice means that all living things have the opportunity to live, while healthy means that organic farming takes into account all aspects of life, both the soil, humans, animals and the whole of the universe (www.ifoam.bio, 2018).

Motives as an impulse to do or not do something can be divided into 1) pure altruism, 2) warm glow and impure altruism. Pure altruism is defined as a preference in which a person behaves well to another person or thing. On the other hand, a warm glow motif is defined as a feeling of happiness when someone engages in positive activities, such as doing alms. Meanwhile, impure altruism is a combination of pure altruism and warm glow (Konow, 2007). Warm glow and altruism can stand alone, but the two can be related to each other. The greater the human feeling to be unselfish, the higher the personal satisfaction to take selfless actions (Andreoni, 2007).

Regarding organic farming, the prices of organic products currently tend to be higher when compared to agricultural products from non-organic farming. The conversion of farming systems from nonorganic farming to organic farming is undoubtedly influenced by several factors, one of which is the motive. In this case, the motif can be divided into economic motives and non-economic motives. Economic motives include farmers' expectations to get a higher price than non-organic product prices. 
Meanwhile, non-economic motives are associated with farmers' awareness of environmental improvement efforts through environmentally friendly agricultural practices.

Research through motives, both economic and non-economic, is essential because it relates to farmers' decision making to continue-or not to continue organic farming (willingness to continue). In certain circumstances where the price of organic agricultural products is not higher than conventional products, non-economic motives are essential to be discussed concerning the sustainability of the farm.

\section{RESEARCH METHODS}

The primary method used in this study is a descriptive method, which is a research method that focuses on a problem at present by collecting data, compiling, and analyzing it. The descriptive way is intended for careful measurement of social phenomena (Singgarimbun and Effendi 1995), while according to Nasir (1988), the descriptive method aims to describe the relationship between the events investigated, test hypotheses, and make predictions and implications of a problem to be solved. In a descriptive way, the data are analyzed individually using descriptive analysis. Loeb et al. (2017) stated that descriptive analysis could stand alone as a result of research to recognize patterns from a phenomenon that has not been recognized before. Descriptive analysis is relevant for all studies and helps researchers in explaining a case.

The descriptive method in this research is used to determine the socio-economic conditions of farmers as one of the fundamental things to explore the economic motives of farmers and also to analyze the farmer's motives. According to Gabor (2010), descriptive analysis is appropriate for identifying dimensions and basic factors in explaining correlations on several variables.

The study conducted in the Special Province of Yogyakarta and Magelang covers. This research was conducted for 8 (eight) months, starting from March to November 2019. Respondents in this study were 29 people, organic rice farmers who have been in farming for more than three years consistently. To find out the motives of altruism and economic motives used a questionnaire in the form of a Likert scale (very inappropriate-very appropriate). Level altruism adopted the research of Zwick and Fletcher (2014), which divides altruism into eight levels. The altruistic was analyzed with DMRT (Duncan Multiple Range Test). DMRT test is essential to be used to explain the differences between each level in the altruism measure.

\section{RESULTS AND DISCUSSION}

Agriculture has always been a mainstay sector for a country's economy. Besides, food is also connected with adequate nutrition and community welfare. The issue of food has been started since the beginning of human civilization, pre-independence times, and will remain a focus in national development. The government has issued several policies starting from the independence era of the Republic of Indonesia to support food sufficiency. In the end, the new order was designated as the era of Indonesian agricultural development initiation through the REPELITA (Rencana Pembangunan Lima Tahun) program. BIMAS (Bimbingan Massal) Gotong Royong (1969-1970) was the flagship program in the five years of development planning, which called REPELITA. Through this BIMAS Gotong Royong program, the government shows its seriousness in agriculture. Some of the derivative programs produced are the distribution of fertilizers, seeds, and pesticides, as well as ensuring food channels from rural to urban areas. The BIMAS program itself is one of the programs derived from the Green Revolution. The main focus in the Green Revolution was on providing food for the people through the use of chemical fertilizers, the introduction of technology, and the use of superior varieties.

The Green Revolution became an unsustainable program after the economic crisis in 1998. After the crisis period, Indonesia's food sufficiency milestone became unstructured. Besides, the social impact of the Green Revolution is the situation of farmers who are affected by large companies producing seeds and seeds of superior varieties and are unable to escape the need for pesticides and other chemicals.

Synthetic chemicals cause pests and plant diseases to become more resistant as well as reduce soil quality. This condition shows an alarming situation. Threats not only come from the carrying capacity of environmental land that is increasingly declining as well as threats to public health over the use of chemicals in the long run. The situation has led to a new paradigm known today as the organic agriculture paradigm.

The history of organic agriculture in Indonesia can not be separated from the establishment of WALHI (Wahana Lingkungan Hidup) in 1980 until the Go Organic program in 2010 and the preparation of the Indonesian National Standard (SNI) in 2016 which regulates organic agriculture (Ardiansyah, 2015). To change the attitude of farmers who originally depended on chemicals to the new paradigm of organic farming is not easy. Motivation becomes an important part that drives human 
behavior. Motivation is an impulse that arises from within a person as a result of unmet needs. Motivation is a psychological process that reflects the interaction between attitudes, needs, perceptions, and decisions that occur in a person (Saputra and Samuel, 2013). Motivation and motives are two things that are inseparable from one another. Motivation is an interaction that can move motives in humans.

\section{Organic Farming Motives}

In general, a program introduced to farmers begins with program socialization and training. Also, Table 1. Types of Farmers' Motivation in Organic Rice Farming

\begin{tabular}{cllc}
\hline No & \multicolumn{1}{c}{ Items } & Motive Category & $\begin{array}{c}\text { Percentage } \\
(\%)\end{array}$ \\
\hline 1 & $\begin{array}{l}\text { Organic farming is more profitable } \\
2\end{array}$ & $\begin{array}{l}\text { Economic } \\
\text { non-organic }\end{array}$ & 15.8 \\
3 & $\begin{array}{l}\text { Organic farming provides healthy food } \\
\text { Economic }\end{array}$ & Non-economic \\
5 & $\begin{array}{l}\text { Organic farming is easier } \\
\text { Making organic agriculture more }\end{array}$ & Non-economic \\
independent & $\begin{array}{l}\text { Non-economic } \\
\text { Promote organic farming to maintain soil } \\
\text { fertility }\end{array}$ & Non-economic & 03.2 \\
7 & $\begin{array}{l}\text { Cultivating agriculture for spiritual } \\
\text { reasons }\end{array}$ & Non-economic & 10.5 \\
8 & $\begin{array}{l}\text { Trying to farm because it went along } \\
\text { with friends }\end{array}$ & Non-economic & 0.0 \\
\hline
\end{tabular}

Source: Primary data analysis, 2019

Based on Table 1, it is known that the economic motive in the form of higher organic product prices has a higher percentage compared to other economic motives: organic farming is considered to be more profitable. Supported by the existence of Table 2, it is known that the price per kilogram of organic unhauled rice is IDR 5,089.00. This value is higher than the price of non-organic rice products, which is only IDR4,759.00. The existence of organic farming provides more benefits for farmers, which has not become a dominant motivation because, at present, some of the respondents are still in a period of conversion from non-organic to organic farming. Even so, farmers have felt the harvest from this conversion system, which is claimed to be healthy rice with a higher selling price compared to nonorganic agricultural products.

Besides, in the category of non-economic motives, it is known that providing healthy food is the motivation most chosen by respondents. Brainstorming provided by extension agents or actors who have a role in the diffusion of organic technology makes health as a significant issue to arouse farmers' enthusiasm in conducting organic rice cultivation. This case causes farmers to believe incentives are given as a form of program attractiveness. The motivation currently received by farmers is in the way of economic incentives, namely farmers get a higher selling price of organic unhulled rice when compared to unhulled rice harvested from conventional cultivation systems.

The motivation of farmers in carrying out rice farming with organic systems is shown in Table 1 . The motives are divided into two categories, namely economic motives and economic motives. Agricultural economic variables referred to in this study are profit and product prices. 
practices that require inputs that can be obtained from the surrounding environment. Conventional types of agriculture require inputs that cannot be obtained independently because these inputs are generally chemically based. The use of vegetable pesticides and organic fertilizers in organic farming is highly recommended. Farmers can make organic fertilizers and vegetable pesticides by using materials that are easily found and at a low cost.

The conclusion of the motives that dominate farmers for organic farming is shown in Figure 1.

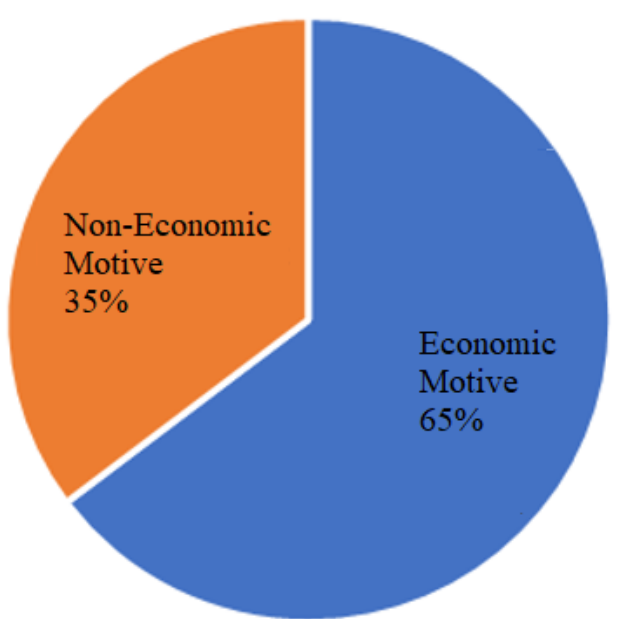

Figure 1. Domination of Motives in Organic Farmers

Figure 1 shows a general description of the motives of farmers in organic farming. Based on the results of surveys in the field, it is known that the majority $(65 \%)$ of farmers do organic farming on the basis of economic motives. Economic motives have been explained in Table 1, which is related to prices and benefits obtained. Financial motives are thought to be motives that, in the short term, can be felt directly by farmers in the form of acceptance of products sold, while non-economic motives tend to be felt only by farmers in the long run. The majority of farmers working on organic rice farming in a relatively short period of time is three years. This is the basis of farmers' conclusions that organic rice farming is profitable.

On the other hand, organic rice farming, which is applied in the last three years, is suspected of having not been able to provide a non-economic impact that is clearly felt by farmers. Given this fact, further research is needed with farmer respondents who have been working on organic rice farming for quite a long time. The social and economic characteristics of the respondents are shown in Table 2 to support the facts about the motivation and motives of organic rice farming.

Table 2. Social and Economic Characteristics of Organic Farmers

\begin{tabular}{clr}
\hline No & \multicolumn{1}{c}{ Characteristic } & Average \\
\hline 1 & Length of being a farmer (years) & 27.8 \\
2 & Length of being an organic farmer (years) & 4.6 \\
3 & Non-organic productivity (tons / ha) & 4.5 \\
4 & Productivity during organic (tons/ha) & 4.1 \\
5 & The average selling price of organic GKP (IDR / kg) & 5,089 \\
6 & The average selling price of GKP (IDR / kg) & 4,759 \\
7 & Farmer's income for one year (IDR / year) & $10,991,945$ \\
\hline
\end{tabular}

Source: Primary data analysis, 2019

Based on Table 2, it is known that the average respondent has been a rice farmer for 27.8 years. The average age of the respondents in this study was 56 years old, so that farmers, in general, were farmers who had learned the cultivation techniques by using the experience gained during that period. The initiation of organic farming implies that farmers also receive training in organic cultivation techniques. However, because organic rice farming has only been running for 4.6 years and is generally still in a conversion period, the productivity of organic rice farming is still lower compared to non- 
organic farming. The period of conversion from non-organic farming to organic farming has a risk of decreasing productivity when compared to productivity during non-organic farming.

The average selling price of organic grain products is known to be higher than non-organic grain. The price difference received by farmers is one of the economic incentives received by farmers. The income of farmers for one year has an average of IDR $10,991,945$, so that during one planting season, IDR 3,663,981. Meanwhile, the average organic rice farming revenue was IDR 7,260,474 for one growing season. Thus the $\mathrm{R} / \mathrm{C}$ ratio of organic rice farming is 2.05 . This means that for everyone, rupiah costs incurred will generate IDR 2.05 in revenue. By using $\mathrm{R} / \mathrm{C}$ rules, this farming is concluded to be feasible.
Although economic motives are the dominant motive in organic rice farming, non-economic motives also appear in organic rice farming. Noneconomic motives are measured specifically through altruistic levels. According to Singer (1979) in Jena (2018) states that the superiority of altruism levels in humans is not limited to altruism due to the act of reciprocation.

Altruism in humans is driven and motivated by rational and impartial considerations. So when humans do altruistic actions, this is no longer influenced by whether other humans have been kind or not to him. Altruistic acts are more a form of caring. Caring is one of the characteristics that humans have the nature of sentience (feel). The results of research on altruistic levels are shown in Table 3 .

\section{Domination of Noneconomic Motives: Altruism}

Table 3. Altruistic Level Ranking Results

\begin{tabular}{lcc}
\hline \multicolumn{1}{c}{ Level of altruism } & Average Score* & Rank \\
\hline Self-interest (1) & $14,2^{\mathrm{c}}$ & 6 \\
Kin altruism (2) & $12,14^{\mathrm{de}}$ & 8 \\
Interaction based altruism (3) & $10,76^{\mathrm{f}}$ & 3 \\
Group altruism (4) & $15,45^{\mathrm{b}}$ & 1 \\
Human altruism (5) & $17,89^{\mathrm{a}}$ & 7 \\
Sentience altruism (6) & $11,35^{\mathrm{ef}}$ & 2 \\
Life altruism (7) & $15,76^{\mathrm{b}}$ & 5 \\
Being altruism (8) & $13,07^{\mathrm{d}}$ & 4 \\
\hline
\end{tabular}

(* the same index shows no significant difference at the $95 \%$ significance level) Source: Primary data processing, 2019

According to Rifkin (2010), in Zwick and Fletcher (2014), altruism is an action that benefits others but is relatively detrimental to oneself. However, altruism emphasizes empathy. The fundamental thing in altruism is the personal self, so the first level of altruism refers to self-interest. Personal interest in the concept of organic rice cultivation becomes important without any desire within oneself; motives cannot change into a behavior.

At this level, Zwick and Fletcher (2014) state that people do not behave as humans should, and do not involve rationality. Level 2 to level 7 shows the empathy circle from the narrowest circle to the broader outer circle. Kin altruism shows empathy in the immediate environment (clan). Kin altruism motives in organic rice farming are farmers conducting organic rice cultivation in the context of providing healthy food for their immediate family. At level 3, interaction-based altruism, that altruism is a prosocial action. Simpson and Willer (2007) state that prosocial activities are based on interactions between people and situations. Interaction with others results in a farmer being provoked into organic rice cultivation activities. The next level is group altruism. Supported by the same literature, Simpson and Willer (2007) altruism become a prosocial activity because, through this activity, a person is driven to improve the welfare of others even though in altruism actions, the cost loss is borne by oneself. At this level, farmers' reluctance to carry out organic-based farming activities began to be influenced by the awareness to help others outside their immediate family even though at a cost, the farmers bear a loss.

The group referred to here is the deepest interaction circle due to similarity, for example, the similarity of hobbies, activities, and religion. In organic rice cultivation activities, it can be concluded that farmers carry out organic rice cultivation because, in general, the farmer groups are given a mandate by the local, regional government to be used as an experimental farmer group (in groups). 
The level of human altruism, altruism with fellow human beings is not the highest in altruism, because human altruism states that altruism occurs because of the reciprocity relationship which impacts on the existence of the perpetrator's reputation. At this level, altruistic motives will also decrease as the costs needed increase over time (Fehr and Fischbacher, 2003). Farmers will continue to be altruistic by continuing to cultivate organic rice. Still, if the human altruism motive becomes the main, the altruistic motive will decrease along with the magnitude of the sacrifice made by the farmer. Nevertheless, in this study, human altruism statistically has the highest score, among others.

At the next level, sentiment altruism is usually associated with feelings of respect for the lives of others, including other creatures. So that at this level, the motive for altruism is no longer related to fellow human beings but rather how humans value the lives of other creatures besides humans (animals and plants). With the altruistic motive at the level of sentience, organic farmers think about not only the survival of the family but also the existence of other organisms such as frogs, snakes, and birds. Based on the results of in-depth interviews, respondents said that organisms that were originally thought to be extinct, re-emerged when organic farming is carried out.

They are related to the next level, life altruism, after farmers feel that other living things re-exist around them, furthermore life altruism will encourage farmers to care more about the total environmental conditions, for example, the better soil conditions.

At the last level, being altruistic, altruism leads to a state of respect for other beings as high as the human being itself or even higher. Zwick and Fletcher (2014) state that the levels do not indicate a better level between one level and another. In Figure 2 and Table 3, it is known that the highest altruism score is in the human altruism component. Human altruism shows that farmers carry out organic rice cultivation activities driven by the desire to sacrifice for other humans. Even so, at this level, when at one time the costs issued by farmers were overvalued, the altruistic feeling would decrease yet though farmers could still be classified as charitable. Human altruism shows that exploiting other species is not an expression of empathy. So, at this level, the farmer has realized that another creature or entity, for example, land (land), becomes an entity that should not be exploited. The second-highest scoring level is life altruism. At this level, farmers respect the whole environment, not only living things but also nonliving things.
The results of this research show that human altruism and life altruism support each other. At both of these levels, altruistic motives are no longer related to themselves but rather involve other parties outside the farmer. This means that organic farmers have the awareness to respect other creatures.

Regarding the policy implications, economic incentives are still needed in encouraging organic farming programs. Organic farming has considerable potential opportunities to be developed when viewed from the altruistic level owned by farmers.

\section{CONCLUSION}

Economic motives still dominate the motives of farmers in conducting organic rice farming. Nonetheless, non-economic motives do not mean that they do not appear but appear in lower domination when compared to economic motives. Non-economic motives related to altruism indicate that altruism level scoring is at the level of human altruism, and life altruism means, organic farmers have an awareness to respect other living creatures. This research requires further research that is more comprehensive, both in terms of method and number of samples.

\section{ACKNOWLEDGEMENTS}

Faculty of Agriculture, Universitas Gadjah Mada for funding the research.

\section{REFERENCES}

Andreoni, J., (2007). Altruism in Experiments. Prepared for the New Palgrave Dictionary of Economics, 2nd Edition

Ardianysah, D.W., (2015). Organic agriculture in Indonesia: challenges and opportunities. Springer.

Fehr, E and U. Fischbacher. (2003). The nature of human altruism. Nature | Vol 425 | 23 October 2003 | www.nature.com/nature

Konow, J., (2007). Mixed Feelings: Theories and Evidence of Warm Glow and Altruism. Online at http://mpra.ub.uni-muenchen.de/2727/ MPRA Paper No. 2727, posted 14. April 2007

Gabor, M.R. (2010). Descriptive Methods of Data Analysis For Marketing Data-Theoretical And Practical Considerations. Management \& Marketing Challenges for Knowledge Society, 5, 119-134. 
Gevisioner, Febriamansyah, R., Ifda dan Tarumun, S. (2017). Kegagalan Pembangunan Pertanian Meningkatkan Kesejahteraan Petani Di Indonesia. Kegagalan Pembangunan Pertanian Meningkatkan Kesejahteraan Petani di Indonesia, prosiding.

Jena, Y. (2018). Altruisme Sebagai Dasar Tindakan Etis Menurut Peter Singer. RESPONS 23, 5982

Loeb, S., S. Dynarski., D. McFarland, P. Morris, S.Reardon, S. Reber. (2017). Descriptive Analysis in Education: AGuide For Researchers. National Center for Education Evaluation and Regional Assistance, USA.

Nasir. (1988). “Metode Penelitian.” Jakarta: Galilea Indonesia.

Rifkin, J. (2010). The emphatic civilization: the race to global consciousness in a world of crisis. Penguin, New York.

Rigby, D., \& Ca, D. (2001). Organic Farming And The Sustainability Of Agricultural Systems, $68,21-40$.
Simpson, B and R. Willer. (2007). Altruism and Indirect Reciprocity: The Interaction of Person and Situation in Prosocial Behavior. Simpson, Department of Sociology, University of South Carolina, Columbia SC 29208 or e-mail bts@sc.edu

Singer, P. (1979). Practical Ethics, Cambridge University Press, Great Britain. www.ifoam.bio

Singgarimbun, M, and S Effendi. (1995). "Metode Penelitian Survei.” Yogyakarta: LP3ES.

Saputra, P. Dan H. Semuel. (2013). Analisa Pengaruh Motivasi, Persepsi, Sikap Konsumen Terhadap Keputusan Pembelian Mobil Daihatsu Xenia Di Sidoarjo. Jurnal Manajemen Pemasaran 1, 1-12

Suwantoro, A.V. (2008). Analisis Pengembangan Pertanian Organik Di Kabupaten Magelang (Studi Kasus Di Kecamatan Sawangan). Universitas Diponegoro, Semarang.

Zwick, M., and J.A Fletcher. (2014). Level of Altruism. Biol Theory 9, 100-107. 
This page is intentionally left blank 